\title{
THE UNBEARABLE WRONGNESS OF BUSH V. GORE
}

\author{
Laurence H. Tribe*
}

\section{INTRODUCTION}

Again? Another article about Bush v. Gore? ${ }^{1}$ Is there anything of substance left to say that has not already been said? I think there has to be-as long as there remain serious observers who react to the Supreme Court's announced equal protection rationale for its stop-the-counting ruling with anything but headscratching incredulity, and as long as trying to figure out how they convince themselves that the Court's rationale made sense reveals something of interest and importance about constitutional law. How one reacts to the Court's equal protection rationale is, of course, affected to some degree by one's disposition toward the results it produced-although Nelson Lund, for his part, seems far too focused on rationalizing his desired result to see that law professor-non-litigants are no less susceptible to "acquired conviction syndrome" than are law professorlitigants.

* Tyler Professor of Constitutional Law, Harvard Law School. For his extraordinarily able assistance in the preparation of this comment, I am indebted to Michael $J$. Gottlieb, who will receive his J.D. degree from Harvard Law School in June 2003. A remarkable student, research assistant, and teaching fellow, Mr. Gottlieb deserves much credit for whatever is right about this essay. For her splendid editorial assistance, I owe my thanks also to Rebecca Onie, another remarkable student and research assistant who will receive her J.D. in June 2003. For whatever remains wrong with this essay, the blame rests squarely with me. The essay's title was inspired by Nelson Lund, The Unbearable Rightness of Bush v. Gore, 23 Cardozo L. Rev. 1219 (2002). I must leave to the reader whether any part of this exchange deserves to be linked even nominally with Milan Kundera's luminous Unbearable Lightness of Being.

1. 531 U.S. 98 (2000).

2. Professor Lund accuses me of suffering from this syndrome-apparently the result of my role as counsel to Vice President Gore during both the federal and state litigation surrounding the Florida election dispute. See Nelson Lund, "EQUAL PROTECTION, MY ASS!'?, Bush v. Gore and Laurence Tribe's Hall of Mirrors, 19 Const. Comm. 543, 543 (2003) ("Lund, EQUAL PROTECTION"). Nowhere in my Harvard Law Review comment did I ever claim to be a disinterested observer. Quite to the contrary, I disclosed my professional and emotional involvement in the dispute, see 
For Professor Lund, an attempt to write a "disinterested" response to an "unexceptional" article of "daunting volume" and "genuinely indefensible" conclusions ${ }^{3}$ has produced what is undoubtedly the single most partisan and unself-critical defense of the per curiam opinion in Bush v. Gore-a defense that is, to borrow what foreign affairs columnist Tom Friedman once aptly said of Benjamin Netanyahu, "deeply, deeply shallow." While most defenders of the decision have at least struggled with the difficult questions it poses-whether the Equal Protection Clause mandates precisely drawn and completely uniform standards for recounting electoral ballots; whether Article II imposes substantive constraints on a state court's power to interpret its own state election laws; when federal judicial resolution of state ballot-counting disputes intrudes too far into the responsibilities of the coordinate political branches; when the interests of finality and stability instead justify such federal judicial intrusion and might even justify abandoning some voters' rights to have their ballots counted-Professor Lund seems to find all these problems easy. Bush v. Gore's critics have not agreed on just where the Court went wrong, and even most of the decision's defenders, after noting the uniquely hurried and thus arguably extenuating circumstances in which the Court acted, have found something significant to criticize in what the Court did and in what it said. But not Professor Lund. For him, Bush v. Gore was "simply not a close case."4 Lund's loyalty to each argument, idea, and even word used by the Court is, to my knowledge, unmatched in

Laurence H. Tribe, eroG .v hsuB and its Disguises: Freeing Bush v. Gore from its Hall of Mirrors, 115 Harv. L. Rev. 170, 178-79 (2001), and left to the reader the task of determining whether I had succeeded in offering a persuasive account of the Court's decision.

Professor Lund admits that he wanted to see then-Governor Bush become President, yet seems to believe he is immune from acquired conviction syndrome. See Lund, EQUAL PROTECTION at 545 (describing his analysis as "disinterested"). Notably, Professor Lund was a Bush-campaign cheerleader from the first days of the dispute; as the controversy evolved he launched a series of acerbic attacks on the Florida Supreme Court, the Gore campaign, and any observer who expressed sympathy for either. See, e.g., Nelson Lund, Travesty in Tallahassee, Wkly. Std. 17 (Dec. 18, 2000). Although Lund argued in his capacity as campaign observer that the "only sane approach is to count the votes according to the laws in place on November 7 , and accept that result" id, his hindsight-informed conclusion was that the federal judiciary should step in to halt the counting of votes according to those laws if the state's highest court construes that state's laws as authorizing "'any method or means' of weighting votes differently depending on where the voters reside." Lund, EQUAL PROTECTION at 551-52.

3. These are all direct quotations from Lund's characterization of my Harvard Law Review comment. See Lund, EQUAL PROTECTION at 543-45 (cited in note 2).

4. Nelson Lund, The Unbearable Rightness of Bush v. Gore, 23 Cardozo L. Rev. 1219, 1249 (2002) ("Lund, Unbearable Rightness"). 
the academic community. ${ }^{5}$ Methinks the Professor doth protest too little.

In writing this comment, I have resisted the temptation to provide yet another version of the events leading up to the Supreme Court's now famous - or infamous-decision of December 12,2000 . I have already provided a more detailed account than space here will permit, ${ }^{6}$ and many other thoughtful histories exist. $^{7}$ As a result, this comment jumps straight into the deep end of the proverbial pool, assuming all the while that the reader has at least a modest degree of familiarity with the Election 2000 controversy. In Part I, I defend my belief that the Court's per curiam opinion cannot be grounded in any previously recognized form of the Equal Protection Clause. I first respond to Professor Lund's suggestion that Bush v. Gore was nothing more than a logical extension of "one-person, one-vote" voting rights jurisprudence. I then argue that the Court's failure to grapple with the underlying equal protection issues, and its particularly inexplicable failure to grasp the inconsistency between its own equal protection holding and the remedy on which it settled, evince the almost embarrassing bankruptcy of the rationale the Court's majority adopted.

In Part II, I argue that Bush v. Gore presented a political question that most likely never should have been decided-and, at a minimum, provided an answer that never should have been given-by a federal court. In the course of making that argument, I confess both the error of my insufficient attention to the political question problem during the heat of the litigation itself,

5. For examples of more balanced contributions to this debate, see generally Richard A. Posner, Bush v. Gore as Pragmatic Adjudication, in Ronald Dworkin ed., $A$ Badly Flawed Election (Debating) Bush v. Gore, the Supreme Court, and American Democracy 187-213 (New Press, 2002) (defending the decision on crisis-avoidance grounds); Richard A. Posner, Breaking the Deadlock: The 2000 Election, The Constitution, and the Courts (Princeton U. Press, 2001) (defending Bush v. Gore both on Article II and crisisavoidance grounds); Michael W. McConnell, Two-and-a-Half Cheers for Bush v. Gore, 68 U. Chi. L. Rev. 657 (2001) (defending most of the decision but critiquing the remedy imposed by the Court); Richard H. Pildes, Democracy and Disorder, 68 U. Chi. L. Rev. 695 (2001) (arguing that Bush v. Gore followed naturally from the Court's vision of democracy); John C. Yoo, In Defense of the Court's Legitimacy, $68 \mathrm{U}$. Chi. L. Rev. 775 (2001) (defending the Court against critiques made against its legitimacy but criticizing it for its equal protection rationale and remedy).

6. See Tribe, 115 Harv. L. Rev. at 179-84 (cited in note 2).

7. See generally Abner Greene, Understanding the 2000 Election: A Guide to the Legal Battles That Decided the Presidency (New York U. Press, 2001); E.J. Dionne Jr \& William Kristol eds., Bush v. Gore: The Court Cases and the Commentary (Brookings Institute Press, 2001); Larry J. Sabato ed., Overtime! The Election 2000 Thriller (Longman, 2002). 
and the error of my overly mechanical formulation of the "political question" question in my first scholarly analysis of the dispute - published a year later in the Harvard Law Review. And I offer a considerably more nuanced formulation that rejects both Professor Lund's position that the question before the Court was manifestly a justiciable one and my own Harvard Law Review position that the question was categorically non-justiciable, advancing instead a "political process" doctrine according to which political nonjusticiability, in an important class of instances, is akin to nonjusticiability for want of ripeness-rather like a species of failure to exhaust available remedies.

\section{THE UNSURPRISINGLY SHOCKING EQUAL PROTECTION RATIONALE}

To say that the equal protection holding adopted by the per curiam opinion in Bush v. Gore was shocking is simply to describe a psychological and cultural reality: as even Professor Lund concedes, most non-specialists viewed the decision as "quite startling, and transparently dishonest." 8 Scores of academics agreed. I think the technical term for the standard reaction at the time would have to be the one Keanu Reeves voiced in The Matrix: "Whoa!"

What are we to make of that reality? If we regard the Constitution as an arcane repository of rules whose meaning is accessible only to a specialized elite, then we might respond with a shrug and reason that, if all but a handful of constitutional lawyers fail to see why the Court's analysis was correct, all that follows is that most Americans, including most law professors, would be unlikely to earn high grades in an exam on equal protection law. But if instead we share the vision that the task of expounding the Constitution ${ }^{10}$ as our nation's fundamental law entails communicating its contents to the people at large and engaging them in a conversation about its commands, its aspirations, and its shortcomings, ${ }^{11}$ then so dramatic a disconnect be-

8. Lund, EQUAL PROTECTION at 548 (cited in note 2).

9. See Law Professors for the Rule of Law at <http:/www.the-rule-oflaw.com/archive/supreme/> (last visited December 29, 2002) (noting support of 673 law professors in denunciation of the Bush $v$. Gore ruling).

10. See McCulloch v. Maryland, 17 U.S. (4 Wheat.) 316, 407 (1819) ("we must never forget, that it is a constitution we are expounding").

11. See id. (emphasizing importance of public understanding of the Constitution and the resulting necessity that it not "partake of the prolixity of a legal code"). As Justice Hugo Black is said to have told Walter Dellinger when Dellinger served as his law 
tween what the Court says and what people find credible ought to be disconcerting.

Although by December 2000 the Court's stock of political and moral capital sufficed to enable it in essence to dictate the succession to the presidency, through the agency of the electoral college, of the candidate with half a million fewer popular votes nationally than his opponent - and to do so with a 5-4 decision announced in an opinion that the overwhelming majority of informed observers found incoherent-the brute fact that the opinion and the ruling it rationalized seemed to come out of nowhere and failed to make the slightest sense to those who were told the vote-counting had to stop ${ }^{12}$ itself therefore counts heavily, although not decisively, against the Court's action, even before we consider on their merits the legal arguments offered in its support.

The battle cry that the Florida Supreme Court had been guilty of changing the state legislature's definition of a lawfully cast vote or of the applicable deadlines, perhaps for partisan reasons, after the polls had closed and thus violating due process or Article II of the Constitution ${ }^{13}$ - the principal claim that had been used to make a federal case out of it from the outset-had, in the end, proven too weak to persuade more than three of the Court's nine Justices. ${ }^{14}$ All that remained was the claim, perplexing on the face of it, that equal protection of the laws required giving no protection of the laws to the thousands of still uncounted ballots. Because ballots that looked the same might get counted differently under the Florida Supreme Court's approach depending on when and where they were counted, much larger differences among precincts using dramatically different ballots or counting methods, and between the ballots that were counted and those that were not, had to be ignored-and that in the name of equal protection of the laws! Professor Lund's effort to enlist the support of two of the four dissenting justices for that equal protection holding, the better to fend off the charge that the holding was not just incorrect but utterly bizarre, rests on a

clerk in 1968-69, "Write it so your Mamma can understand it." Joseph Goldstein, The Intelligible Constitution: The Supreme Court's Obligation to Maintain the Constitution as Something We The People Can Understand 112 \& n.9, 190 (1992).

12. See note $76-78$.

13. U.S. Const., Art. II ("The President of the Senate shall, in the presence of the Senate and House of Representatives, open all the Certificates and the votes shall then be counted.").

14. Only Justices Scalia and Thomas joined the Chief Justice's concurring opinion relying on Article II. Bush v. Gore, 531 U.S. 98, 111 (2000) (Rehnquist, C.J., concurring). 
transparent exaggeration of what Justice Breyer wrote on the subject ${ }^{15}$ coupled with an obvious fallacy: Lund equates the view that equal protection might have required some improvements in the counting method put in place by the Florida Supreme Court with the view that freezing the status quo in mid-count might somehow represent the equal protection of the laws. ${ }^{16}$

Against that backdrop, I make no apology for expressing my solidarity with the public outrage and frustration that was concisely if crudely expressed in the logo, "Equal Protection My Ass!", whose appearance on buttons worn by Gore-Lieberman supporters within hours of the Court's decision bespoke not contempt for the Court but disdain for its stated rationale. ${ }^{17}$ Such disdain made sense, of course, only if one began with the premise, expressed with some frequency by the Court itself, that the "Court must take care to speak and act in ways that allow people to accept its decisions on the terms the Court claims for them, as grounded truly in principle, not as compromises with social and political pressures having, as such, no bearing on the principled choices that the Court is obliged to make." 18

15. See Bush, 531 U.S. at 145-46 (Breyer, J., dissenting) (agreeing only that the Florida recount scheme "implicate[d] principles of fairness" that, given the "very special circumstances," may well have "counseled the adoption of a uniform standard to address the problem"). As I have made clear before (and will do again later), the claim that seven Justices "adopted" the Court's equal protection holding is inaccurate. See text at notes 132-136; Tribe, 115 Harv. L. Rev. at 258 n.361 (cited in note 2).

16. To dismiss that as "just" a debate about remedies is like asking: "Apart from that, Mrs. Lincoln, how did you like the play?"

17. I'm frankly baffled that Professor Lund would choose that vulgar slogan for his title and for the centerpiece of his reply-or, for that matter, would use the phrase more than half a dozen times in his text. In eroG. $v$ hsuB, I mentioned the slogan twice: once to introduce it, and once to underline my conclusion that a careful examination of each possible rationale that might be used to defend the per curiam opinion revealed how justified was the utter frustration expressed by the wearers of those buttons. See Tribe, 115 Harv. L. Rev. at 221, 247 (cited in note 2). Yet, like a child irrepressibly fixated on an adult's use of a dirty word, Professor Lund has chosen to make the slogan on that button-admittedly a tasteless and imperfect expression of emotions ranging from disbelief to rage-central in his critique. In so doing, he has made a regrettable rhetorical move, reframing my dissection of Bush $v$. Gore as a juvenile and disrespectful assault on the Supreme Court. But of course it was nothing of the sort, as any reasonable reading of my painstaking 135-page comment would reveal. Of particular interest in that regard should be the section in which I attempted to explain how Bush v. Gore fits into a now familiar pattern of political process cases decided by the Rehnquist Court. Id. at 247-54, 287-90.

18. Planned Parenthood of S.E. Pa. v. Casey, 505 US 833, 865-66 (1992) (plurality opinion of Justice O'Connor, Kennedy, and Souter). See generally Joseph Goldstein, The Intelligible Constitution (cited in note 11). 


\section{A. A "ONE-BALLOT, ONE-VOTE" DOCTRINE?}

Professor Lund believes that the disdain, while widely felt, was misguided, and that a careful reading of the cases cited in Bush v. Gore, of which there were only a small handful, ${ }^{19}$ reveals a doctrinal principle so plain that no disinterested and properly informed observer could find fault with the Court's application of that principle to overturn the Florida Supreme Court's December 8 order. Putting to one side the discomforting elitism implicit in his claims, the main thrust of Professor Lund's doctrinal argument is that the critics of Bush v. Gore, myself in particular, like poorly trained students who slept through the basic course in the subject, have simply confused two distinct categories of equal protection cases: those involving suspect classifications, and those involving fundamental rights. Once one wakes up, separates the two categories, and recalls that voting rights cases of course belong on the fundamental rights branch of the equal protection tree, says Lund, it becomes clear that any differential treatment of voters is subject to strict judicial scrutiny and is therefore presumptively unconstitutional regardless of the presence or absence of discriminatory intent. Any state scheme that treats voter A differently from voter $B$ has at least two strikes against it, constitutionally speaking. Aha! Now it's all clear! How did so many of us manage to forget anything so elementary?

I'll say this much: Professor Lund's approach has the appeal of simplicity going for it. The tougher question is what else there is to be said for it. Consistency with precedent certainly isn't among its virtues. Take the principal case invoked by Professor Lund for the conclusion that the attack on the Florida Supreme Court's December 8 recount order was properly justiciable rather than political: McPherson v. Blacker.$^{20}$ There, the Michigan Legislature in 1891 had chosen to exercise its Article II responsibility of directing a method of selecting the state's presidential electors for the national election of 1892 through a statewide popular election in which individual voters were divided into separate geographical districts and, as a result, treated differently based upon where they lived (in the sense that demographic and political differences among districts might work ei-

19. See Bush, 531 U.S. at $105-07$ (per curiam). The fact that the Court could come up with only three cases to support its equal protection holding is not, by itself, proof that the decision didn't arise from a firm foundation of constitutional doctrine but does add to the burden of anyone who claims that it did.

20. 146 U.S. 1 (1892). 
ther to magnify or to dilute the influence of voters of any given persuasion who find themselves concentrated into relatively few districts rather than dispersed among many). Yet rather than requiring that voters be treated identically without regard to a factor like local residence, the way they are in a system where a single statewide electoral slate is chosen at-large under a winnertake-all system, the McPherson Court unanimously and brusquely rejected the Equal Protection Claim $^{21}$-a holding which the Bush v. Gore Court would have reaffirmed in a heartbeat, ${ }^{22}$ plainly repudiating the simplistic thesis Lund adopts.

In its place there must stand a far richer and more complex (even if rarely articulated) set of assumptions about presumptively acceptable vs. presumptively invalid structures for aggregating the political preferences of individual voters - for assuming some mix of fair treatment of all "groups," variously identified; effective representation of voters generally; openness to political challenge and change; and treatment of all persons as entitled to equal dignity and respect. ${ }^{23}$ As Justice Thomas noted in a widely cited 1994 opinion, even deciding "to rely on singlemember geographic districts as a mechanism for conducting elections is merely a political choice, ${ }^{, 24}$ not a neutral fact of naturejust as deciding to use winner-take-all electoral college system, the decision made by all but two states in the 2000 presidential election, ${ }^{25}$ is a political choice, one with its own mix of consequences for how individual and group preferences are aggregated to yield electoral outcomes and for how various groups, and even the polity as a whole, might in one respect or another be "injured" over time by the resulting structure of political representation.

Of course the McPherson Court was not presented with a sophisticated challenge to the particular method of drawing district boundaries - either in terms of alleged population disparities, intentional or accidental, or in terms of deliberate dilution of the influence wielded by voters of a given race or political

21. Id. at $40-42$.

22. See Bush, 531 U.S. at 104 (per curiam); id at 113 (Rehnquist, C.J., concurring).

23. See Heather $\mathrm{K}$. Gerken, The Costs and Causes of Minimalism in Voting Cases: Baker v. Carr and its Progeny, 80 N.C. L. Rev. 1411, 1419-27, 1448-55 (2002).

24. Holder v. Hall, 512 U.S. 874, 909 (1994) (Thomas, J., concurring in judgment). See also Gerken, 80 N.C. L. Rev. at $1454 \mathrm{n} .172$ (cited in note 23).

25. Maine and Nebraska were the only two states to use modified systems. See Note, Rethinking the Electoral College Debate: the Framers, Federalism, and One-Person, One-Vote, 114 Harv. L. Rev. 2526, 2530 \& n.28 (2001). 
party by techniques of packing or of dispersal. ${ }^{26}$ If it had been, the challenge would have been dismissed as nonjusticiable from the early $1900 \mathrm{~s},{ }^{27}$ until Baker v. Carr ${ }^{28}$ in 1962. After Baker, various subspecies of voting rights challenges would have been entertained, either under the "no-exclusion" rubric of Harper" and its progeny; or under the first-generation "no-dilution" framework of Reynolds v. Sims ${ }^{30}$ and its descendants; or under the second-generation "no dilution" rubric elaborated in cases like Thornburg $v$. Gingles. ${ }^{31}$ In all three categories, the Court's rhetoric and its imagery have gravitated toward notions of individualistic harm; indeed, such notions have been central both to the Court's acceptance of the challenges as justiciable and to the gradual accommodation of conservative commentators to this entire body of jurisprudence. ${ }^{32}$ But, as a number of astute observers-most perceptive among them in this respect, perhaps, being Professor Heather Gerken - have shown, the overarching maxim of "one-person, one-vote," which Professor Lund seems to think can bear the weight of the Bush v. Gore decision, cannot in fact be "designed to vindicate a purely individualistic definition of equality" ${ }^{\prime 33}$ even in its most straightforward application to an equipopulous territorially based scheme of legislative representation, but must "necessarily incorporate[] a structural theory regarding the way votes should be aggregated." ${ }^{34}$

It follows that, even if the Florida Supreme Court's December 8 decision could be said to have launched a scheme under which the "weight" of some individual votes cast in Florida would in some sense be less than the "weight" of other individual votes cast in Florida, that would not by itself even begin to state a prima facie equal protection claim under Reynolds or any other line of authority. ${ }^{35}$ One would need to ask: which groups or

26. For a description of "packing" and "dispersal" (also known as "cracking"), see generally Bernard Grofman, Criteria for Districting: a Social Science Perspective, 33 UCLA L. Rev. 77 (1985).

27. See Giles v. Harris, 189 U.S. 475 (1903). See also Gerken, 80 N.C. L. Rev. at $1464 \&$ n.211 (cited in note 23 )

28. 369 U.S. 186 (1962).

29. Harper v. Virginia Bd. of Elections, 383 U.S. 663 (1966).

30. 377 U.S. 533 (1964).

31. 478 U.S. 30 (1986); see also Lani Guinier, The Triumph of Tokenism: The Voting Rights Act and the Theory of Black Electoral Success, 89 Mich. L. Rev. 1077, 1093-94 (1991).

32. See Gerken, 80 N.C. L. Rev. at 1464 (cited in note 23).

33. Id. at 1453 .

34. Id. at 1453 .

35. Cf. Oregon v. Mitchell, 400 U.S. 112, 127 (1970) (noting that "it cannot be successfully argued that the Fourteenth Amendment was intended to strip the States of their 
categories of votes were being systematically underweighted or undervalued, and to what end? To ask this question does not, as Professor Lund asserts, confuse suspect classification cases with fundamental rights cases. Rather, it recognizes a development in voting rights cases to which Professor Lund seems altogether blind: as the Court has increasingly turned towards the "fairness" of challenged state election laws, it has become increasingly tolerant of laws that classify voters with politics in mind. ${ }^{36}$

To illustrate, in Gaffney v. Cummings, ${ }^{37}$ the Court approved of a gerrymandering scheme explicitly designed to produce safe districts for incumbents. ${ }^{38}$ The Court did not ask whether the state scheme, by placing Democratic voters in predominantly Republican counties (or vice versa), treated voters "unequally" on the basis of geography or party affiliation. Rather, the Court found this "bipartisan gerrymandering" scheme permissible so long as it was not deliberately designed to harm the political strength of any identifiable group. "The reality is that districting inevitably has and is intended to have substantial political consequences." ${ }^{39}$ The Court took this reasoning a step further in Davis v. Bandemer, ${ }^{40}$ insisting that a mere demonstration of dilution of a particular group's voting strength was no longer enough. "Rather, unconstitutional discrimination occurs only when the electoral system is arranged in a manner that will consistently degrade a voter's or a group of voters' influence on the political process as a whole." ${ }^{, 41}$ The relevant test after Davis is thus whether the challenged election practice denies a particular group "its chance to effectively influence the political process." 42

power, carefully preserved in the original Constitution, to govern themselves. The Fourteenth Amendment was surely not intended to make every discrimination between groups of people a constitutional denial of equal protection").

36. See, e.g., Gerken, 80 N.C. L. Rev. at 1417-18, 1438-40 (cited in note 23).

37. 412 U.S. 735 (1973).

38. Id. at 753 .

39. Id.

40. 478 U.S. 109 (1986).

41. Id at 132 (emphasis added).

42. Id.at 132-33. Professor Lund attempts to dismiss the importance of Davis on the ground that it was merely a plurality opinion. Apparently, the reader is supposed to believe that, because Davis commanded no clear majority, the case is not good law. I trust Professor Lund is kidding. First of all, he cites no case to the contrary. Nor could he, for the holding of the Davis plurality has been treated as authoritative: despite the fact that political gerrymandering has been held "justiciable," courts have generally upheld gerrymandering schemes when enacted and defended on the basis of political considerations. See, e.g., Hunt v. Cromartie, 526 U.S. 541, 552 \& n.7 (1999) (noting that political gerrymandering has been held constitutional despite the lack of clear standards by which to adjudicate such claims). Of course, a strong argument can be made that this has been an unsound doctrinal development. See generally John Hart Ely, Confounded by Cro- 
Thus, it should have been obvious that merely pointing to hypothetical differences in the "weight" given to the voters of different counties did not describe the sort of deviation that would suffice to invalidate-either conclusively or presumptively-a scheme designed to ensure the legality and completeness of the total vote count. In that regard, it plainly should have mattered that the manual recounts were neither alleged nor shown to discriminate against any discernable group of voters. Professor Lund seems to recognize as much implicitly when he asserts that the differential treatment present in Bush v. Gore was not random. He accuses the Florida Supreme Court of accepting "one litigant's self-serving requests in a particular election ... at a time when any recount could help only that particular candidate., ${ }^{, 3}$ This formulation is wrong for a number of reasons. First, it is simply not true that the recount could only have helped Gore. Even though Katherine Harris had certified Bush the winner, the election was not yet legally final. ${ }^{44}$ Given the fact that the recount might actually have increased the margin of Bush's lead, it could have solidified the legitimacy of his claim to office rather than offering any comfort to Gore. ${ }^{45} \mathrm{Sec}-$ ond, to the extent that the Florida Supreme Court regarded the state's election laws as requiring an effort to discern and effectuate the intent of the countless voters whose ballots had been dis-

martie: Are Racial Stereotypes Now Acceptable Across the Board or Only When Used in Support of Partisan Gerrymanders? 56 U. Miami L. Rev. 489 (2002); Samuel Issacharoff, Gerrymandering and Political Cartels, 116 Harv. L. Rev. 593 (2002). But see Nathaniel Persily, In Defense of Foxes Guarding Henhouses: The Case For Judicial Acquiescence to Incumbent-Protecting Gerrymanders, 116 Harv. L. Rev. 649 (2002). But Professor Lund does not make that argument. And what's more, one could agree completely with Professors Ely and Issacharoff and say that the Court ought to play a rule in supervising incumbent protecting schemes that block the channels of political change without believing that there should be little or no judicial tolerance for the consideration of politics in the design of systems for recounting ballots. See text at notes 45-67.

Second, as I will discuss later, Justice O'Connor's concurrence, joined by then-Chief Justice Berger and current-Chief Justice Rehnquist, would have gone even farther than the plurality and held that political gerrymandering claims present nonjusticiable political questions. See text at notes 137-139. Thus, a clear majority of the Davis Court was of the view that the political gerrymandering claim at issue did not offend the Equal Protection Clause.

43. Lund, EQUAL PROTECTION at 552 (cited in note 2).

44. See Roudebush v. Hartke, 405 U.S. 15, 25 (1972) (finding that, "[d]espite the fact that a certificate of election may be issued to the leading candidate within 30 days after the election, the results are not final if a candidate's option to compel a recount is exercised" and that a recount is "an integral part of the ... electoral process ... within the ambit of the broad powers delegated to the States by" the Constitution) (emphasis added); see generally Louise Weinberg, When Courts Decide Elections: The Constitutionality of Bush v. Gore, 82 Boston U. L. Rev. 609 (2002) (arguing that elections are not lcgally final until all challenges have been resolved).

45. See note 85 . 
carded, it had no choice but to accept (in a formal sense) the "self-serving" requests of a particular candidate. Why? Because then-Governor Bush refused to request manual recounts, with the result that the only requests before the court were requests to recount the ballots in Gore-leaning counties. Thus, even if the Florida Supreme Court had insisted that any recount be limited to the four Gore-selected counties, which it plainly didn't do, it would not have been judicial activism, but judicial restraint, that guided its decision.

But the link between Bush v. Gore and the voting rights cases, especially Reynolds $v$. Sims, is even more attenuated than that, for at least two reasons.

First, Bush v. Gore did not involve a problem of valuing or weighing some votes more than others, much less deliberately packing or diluting groups of voters, but instead involved the obviously distinct problem of differentially treating ballots as evidence of votes. This is far from an irrelevant factual distinction. ${ }^{46}$ It is a distinction of crucial doctrinal significance.

The Florida Supreme Court's remedy did nothing to alter the manner in which legally cast votes were weighed in the overall state scheme to choose presidential electors. At most, the scheme created the possibility that different standards would be used for determining what constituted a legal vote. In the eyes of the Bush v. Gore majority, the equal protection violation evidently arose when the recount employed standards that, as applied to the circumstances in Florida as of December 8, unacceptably increased the probability that certain voters would have their ballots counted while leaving the probability unchanged for other voters. ${ }^{47}$ But the much maligned "intent of the voter" standard, on its face, treated all voters equally, just as a "reasonable doubt" standard in criminal law treats all defendants equally. It was only in the application of that standard that equal protection violations could have arisen-and even those violations were correctable under the supervision of a single, impartial state judge, about whose role in the process the per curiam opinion said nothing. ${ }^{48}$

46. Lund labels my attempt to distinguish cases like Reynolds on their facts as illegitimate. See Lund, EQUAL PROTECTION at 550-51 (cited in note 2).

47. See Bush v. Gore, 531 U.S. 98, 106 (2000) (noting that "the standards for accepting or rejecting contested ballots might vary not only from county to county but indeed within a single county from one recount team to another").

48. See id at 126 (Stevens, J., dissenting) (noting that the concerns of differing substandards "are alleviated-if not eliminated-by the fact that a single impartial magis- 
The laws challenged in the three cases cited in Bush v. Gore involved injuries of an entirely different genus, let alone species. Reynolds $v$. Sims considered a legislative apportionment scheme with population deviations of up to 41 to 1 in certain districts. ${ }^{49}$ A voter in the state's most populous Senate district knew ex ante that, in order to elect a single representative, she would have to aggregate her vote with 41 times as many voters as would a voter in the state's least populous district. Unlike Bush v. Gore, the state had in place no mechanism capable of correcting the deviation by weighing disparately counted votes equally ex post. Similarly, Gray v. Sanders ${ }^{50}$ involved a challenge to Georgia's countyunit voting system as a basis for counting votes in the presidential primary. The Court found that Georgia's system had the effect of systematically giving more weight to the votes of rural voters at the expense of urban voters. ${ }^{5}$. And in Moore v. Ogil$v i e,{ }^{52}$ the Court reviewed a ballot-access law that required all nominating petitions for presidential electors to obtain their requisite 25,000 signatures from at least 200 qualified voters in at least 50 counties. According to the Court, the law imposed a "rigid, arbitrary formula to sparsely settled counties and populous counties alike." 33 Even the Court's use of the word "arbitrary" is a bit misleading, for the Court's holding unquestionably relied upon the fact that the law made "classifications of voters which favor residents of some counties over residents of other counties. $" 54$

When one compares the Florida recount scheme with the laws in Reynolds, Gray, and Moore, it becomes clear that the two groups of cases involve dramatically different sorts of injuries. No individual voter - and no group of voters identifiable ex ante by any characteristic like place of residence, party affiliation, or, to take the worst case scenario, identity of the candidate for whom the voter appears to have intended to cast his or her ballot-could claim to be harmed by a substandardless "intent of

\footnotetext{
trate will ultimately adjudicate all objections arising from the recount process")

49. 377 U.S. 533, 545 (1964).

50. 372 U.S. 368 (1963).

51. Id. at 379 (finding that the system "in end result weights the rural vote more heavily than the urban vote and weights some small rural counties heavier than other larger rural counties").

52. 394 U.S. 814 (1969).

53. Id. at 818 .

54. Id. at 817 ; see also id. at 819 (stressing that the law "granted greater voting strength" to one group over another, thus discriminating "against the residents of the populous counties of the State in favor of rural sections").
} 
the voter" standard..$^{55}$ Had the statewide recount been allowed to proceed under the supervision of a single judge, no county, for example, could reasonably claim that its votes were being systematically undervalued as compared to those of another county. ${ }^{56}$

What of the exclusion of overvotes in the Florida Supreme Court's recount scheme ${ }^{57}$ Didn't that treat distinct groups of voters differently? Not at all: there is no discernable class of "overvoters," and there is nothing in Reynolds or any other case preceding or following it to suggest that a state cannot be selective in deciding which types of ballot errors it deems worth recounting, subject only to a requirement of rationality. What's more, the entire objection to the Florida Supreme Court's failure to mandate a statewide recount of overvotes while it mandated a statewide recount of undervotes overlooks the crucial fact that thirty-four of Florida's sixty-seven counties examined overvotes for mistakes in the original machine recount and thus submitted, to the final tally on which the Harris certification of November 26 was based, counts that included "classes of voters" that were not similarly counted in other counties. ${ }^{58}$

Despite the fact that Bush v. Gore therefore involved no allegation of an injury or wrong at all analogous to those considered in the traditional one-person, one-vote cases, or indeed in any line of voting rights precedents, Professor Lund defends an extension of Reynolds's "broader principle": the Constitution forbids the weighting of "votes of citizens differently, by any method or means." Now, I am no critic of broad principles as such. Nor do I think that Reynolds was wrongly decided. ${ }^{00}$ Still, Professor Lund makes Reynolds so broad that it becomes impossible to take seriously.

Each state delegates to counties and its local officials substantial discretion in the conduct of elections. This delegation creates a virtually unlimited source of equal protection problems

55. By "substandardless," I mean that the "intent of the voter" standard contained no derivative rule-like criteria to direct local election officials in the task of determining what counted as evidence of a voter's intent.

56. In earlier cases, the Supreme Court had granted considerable deference to state courts in resolving these sorts of equal protection problems. See text at notes 104-110.

57. Overvotes make up the group of ballots that machines originally reject because they are "read" as containing more than one vote for President.

58. See McConnell, 68 U. Chi. L. Rev. at $658 \mathrm{n} .8$ (cited in note 5)

59. See Lund, EQUAL PROTECTION at 551 (cited in note 2) (quoting Reynolds v. Sims, 377 U.S. 533, 555, $563(1964))$.

60 . See id. at 558 . 
under the "broader principle" Professor Lund would extract from Reynolds. The presence of more poll workers in County A might make voting assistance more readily available, thereby "devaluing" the votes of citizens in County B. Meanwhile, County B might use an Accuvote optical scanning device, while County $\mathrm{C}$ uses an older punch card system, thus giving greater weight to a vote cast in $\mathrm{B}$ than one cast in $\mathrm{C} .^{61}$ But if County $\mathrm{C}$ allowed its voters to cast provisional ballots, and County $\mathrm{A}$ did not, the voters of $\mathrm{C}$ might be more likely to cast a meaningful vote than voters in $\mathrm{A}$.

Confused? It gets worse. Consider that the Gray Court held that states may protect the right to have one's vote counted from the diluting effect of illegal ballots. ${ }^{62}$ How, precisely, do states go about ensuring that individual votes are not diluted by fraud? Quite simply, they provide mechanisms for protesting and contesting fraudulent counts on a county-by-county, or precinct-byprecinct basis. Imagine an election in the State of Texas in which several voters in one precinct in Dallas have alleged counting fraud. If Professor Lund's equal protection argument is to be taken seriously, the Constitution would prohibit any process that included any adjustment to that precinct's count unless the adjustment were the result of applying a uniform, statewide substandard. If not, the voters of the other precincts in Dallas, the voters of Houston, and the rest of the voters in Texas would have had their votes systematically devalued.

It is precisely the impossibility of taking the "broad principle" of Reynolds as literally as the Lund argument would take it and applying it to the full range of cases it would address that has led the Court to narrow the decision's reach considerably. Reynolds itself recognized that attention must be given "to the character as well as the degree of deviations from a strict population basis. ${ }^{63}$ Even with respect to the degree of deviation, the Court has moved away from a rigid rule requiring near-perfect

61. See Pamela S. Karlan, Nothing Personal: The Evolution of the Newest Equal Protection From Shaw v. Reno to Bush v. Gore, 79 N.C. L. Rev. 1345, 1364-65 (2001) ("By any reckoning, the machine variability in undervotes and overvotes exceeds the variability due to different standards by factors of ten to twenty. Far more mischief, it seems, can be created by poor methods of recording and tabulating votes than by manual recounts.").

62. Gray v. Sanders, 372 U.S. 368, 380 (1963).

63. Reynolds, 377 U.S. at 581 . See also Brown v. Thomson, 462 U.S. 835,848 (1983) (O'Connor, J., concurring) (“[E]qual representation is not simply a matter of numbers. There must be flexibility in assessing the size of the deviation against the importance, consistency, and neutrality of the state policies alleged to require the population disparities."). 
equality, albeit in limited circumstances. ${ }^{64}$ And with respect to the "character" of deviations, the Court has increasingly permitted deviations so long as the challenged practice does not engage in "discriminatory" treatment of any group of voters. When a legislature's plan "may reasonably be said to advance [a] rational state policy" (or, when the deviation is "supported by substantial and legitimate state concerns"), the inquiry must then take account of whether the state population variations "are entirely the result of the consistent and nondiscriminatory application of a legitimate state policy." 65

Thus, Professor Lund is left with nothing to fall back upon but an argument that the recount's eyeball-based treatment of ballots was impermissible per se. I have already explained why this argument is really just a poor attempt to justify invalidating the recount on substantive due process grounds. ${ }^{66}$ But perhaps more importantly, any claim that the Constitution requires that all ballots be treated identically is indefensible on its face. Indeed, it would make no sense even to insist upon a uniform substandard for all ballots when different types of ballots inevitably will not only bear wildly divergent indicia of intent but will differ in ways that are not random with respect to the locale in which the ballots were cast in the first instance. Would it be arbitrary or unreasonable for a state to create a presumption against recounting undervotes in counties with fancy error-averse systems, but to maintain a presumption in favor of recounting undervotes in counties with antiquated error-prone systems? Certainly not. Yet the Court's equal protection rationale, as Professor Lund defends it, seems to rule out just such a system. And even within the subset of punchcard ballots, "a dimple next to two punched-

64. Thus, in Brown v. Thomson, the Court affirmed an apportionment scheme with an average deviation of $13 \%$ and a maximum deviation of $66 \%$. The Court cited Reynolds for the proposition that, so long as states "make an honest and good faith effort to construct districts ... as nearly of equal population as is practicable," the inevitable deviations that result will be permitted in order to allow states to pursue other "legitimate objectives." Id. (citing Reynolds, 377 U.S. at 577-78). For other examples of large deviations tolerated by the Court, see Bd. of Estimate v. Morris, 489 U.S. 688 (1989); White v. Regester, 412 U.S. 755 (1973); Mahan v. Howell, 410 U.S. 315 (1973).

65. Brown, 462 U.S. at $843-44$. Professor Lund is right to note that this standard departs from the traditional form of strict scrutiny that one might find in other Fourteenth Amendment contexts. See, e.g., Adarand Constructors, Inc. v. Pena, 515 U.S. 200, 227 (1995). Yet neither is such a standard pure rational basis review, for the Court must examine the fit between the deviation from perfect equality and the policy said to advance the state's legitimate interests.

66. See Tribe, 115 Harv. L. Rev. at 237-47 (cited in note 2). 
through holes may not mean the same thing as a dimple next to [ ] two merely dimpled chads." ${ }^{.67}$

It is in this sense that Bush v. Gore appears to put states in a Catch-22: the failure to specify a uniform statewide substandard for recounting may risk invalidation under the "arbitrariness" principle, while the decision to specify such a substandard may inadvertently treat ballots unequally. And this dilemma in turn exposes the absurdity of the Court's freshly-minted "one-ballot, one-vote" principle. Need one actually say it? A ballot is not a person; it is a piece of paper. Often, in order to effectuate the intent of the person behind the ballot, individual pieces of paper must be subjected to case-by-case review. ${ }^{68}$ In its obsessive desire to ensure uniform treatment of ballots, the Court lost focus of the fact that the purpose of the Fourteenth Amendment has always been to protect persons.

The second reason Bush v. Gore seems to be such an odd extrapolation from traditional Fourteenth Amendment jurisprudence is that, even if there were some equal protection objection to be made to Florida's scheme if it were allocating independently fundamental rights, the Bush Court was at pains to state that the franchise being allocated in that case was one extended by the grace of the state legislature performing its federal Article II role. ${ }^{69}$ This was so, the Court's per curiam opinion noted, because the Constitution grants the people no fundamental right to vote in a presidential election. ${ }^{70}$ The Court added that the state legislature could indeed take back what it had given, even after the election had been held. ${ }^{71}$ The right the Court protected was therefore a right to distribution, in accord with a Court-imposed norm, of a privilege that the state was free to withhold altogether. In essence, the Court was telling Florida that it could

67. Id. at 236-37.

68. See Tribe, 115 Harv. L. Rev. at 238-39 (cited in note 2).

69. Bush, 531 U.S. at 104 (per curiam); id. at 112-13 (Rehnquist, C.J., concurring).

70. Bush, 531 U.S. at 104 (per curiam) ("The individual citizen has no federal constitutional right to vote for electors for the President of the United States unless and until the state legislature chooses a statewide election as the means to implement its power to appoint members of the electoral college."). Contrast, for example, the rights granted to the people in elections for members of the U.S. House of Representatives, see U.S. Const., Art. 1, $\$ 2$, or of the U.S. Senate, see U.S. Const., Amend. XVII.

71. Bush, 531 U.S. at 104 (per curiam) (noting that the State "can take back the power to appoint electors ... at any time") (citing McPherson v. Blacker, 146 U.S. 1, 35 (1892)). Some scholars have voiced doubt that this is actually correct. See email from Sanford V. Levinson, Garwood Chair in Law, University of Texas School of Law (Jan. 18,2003 ) (on file with author) (arguing that "the 17 th Amendment, read in its full import, would make it unconstitutional for a state legislature to deprive the people of the right to elect their own electors"). 
choose either to grant a perfectly uniform - as defined ex post in Bush v. Gore - "right" to vote for president or not grant any such right at all.

In this sense, the "right" ostensibly protected by the majority in Bush v. Gore seems characteristic of a class of entitlements that has received only reluctant federal protection from the Rehnquist Court. At least some in the majority-Chief Justice Rehnquist for one $\mathrm{e}^{72}$-in nearly every other circumstance have stated unambiguously that the holder of any such state-tethered entitlement must take the bitter with the sweet. ${ }^{73}$ And even when the Rehnquist Court has rejected this position, it has done so only when the state has either denied the individual entitlement-holder a fair hearing, as in Cleveland Board of Education v. Loudermill, ${ }^{74}$ or employed an invidious or otherwise impermissible criterion of distribution.

Professor Lund's creative deployment of the phrase "EQUAL PROTECTION MY ASS" should not distract the reader from the real slogan at play in his comment: "one-ballot, one vote." It should now be quite clear that Professor Lund has taken that doctrinal title, extracted it from its roots, severed it from its theory in the one-person, one-vote jurisprudence, and extrapolated it mindlessly to processes of recounting to correct errors. Far removed from a "disinterested" analysis, this is the essence of jurisprudence by slogan.

\section{B. OF UNDERLYING INEQUALITIES AND INEXPLICABLE REMEDIES}

Even if one were convinced that the one-ballot, one-vote principle required judicial intervention in Bush v. Gore, it would remain difficult (if not impossible) to justify the Court's decision to halt the entire political and legal process set in motion ${ }^{75}$ and declare by fiat an end to the presidential election. ${ }^{76}$

72. See, e.g., Cleveland Bd. of Educ. v. Loudermill, 470 U.S. 532, 559 (1985) (Rehnquist, J., dissenting).

73. For a more detailed discussion of this point, see Tribe, 115 Harv. L. Rev. at 23437 (cited in note 2 ).

74. 470 U.S. 532 (1985).

75. See Bush, 531 U.S. at 110-11.

76. See, e.g., Weinberg, 82 Boston U. L. Rev. at 629 (cited in note 44 ) (arguing that Bush's successful equal protection claim made him a judgment winner on a claim unrelated to the merits of Vice President's Gore challenge to the election-a challenge that demonstrated without doubt that the originally certified count illegally (under Florida law) excluded ballots-but was not sufficient to justify ending a contest process that by law had to be complete before the election result became "official"). See also Roudebush 
I have already described at length the woeful inadequacy of the Court's explanation for shutting down the recount rather than remanding the case to the Florida Supreme Court. ${ }^{77} \mathrm{I}$ am not alone in this aspect of my critique; the Court's remedy has been criticized by nearly every commentator to consider the issue, and perhaps this is why Professor Lund's most recent work studiously avoids any mention of the issue. ${ }^{78}$ Yet ignoring the issue does not make it go away. And even Professor Lund must admit that he is in a bit of a bind. Assume that the Florida Supreme Court did in fact interpret Florida law, in conjunction with 3 U.S.C. $\S 5$, to impose a mandatory December 12 conclusion to any and all recounts. Also assume that Professor Lund is correct in his reading of Reynolds $v$. Sims: strict scrutiny must be applied to any state judicial decision that in any way burdens or distributes unequally the fundamental right to have one's vote counted. Given the near-universal recognition that countless votes remained uncounted, and given that the underlying count certified by Katherine Harris included a dizzying array of arbitrary inequalities, deferring to the Florida Supreme Court's December 12 deadline would plainly violate the Fourteenth Amendment. ${ }^{79}$ Under Lund's one-person, one-vote theory, the only constitutionally permissible remedy was a remand ${ }^{80}$

v. Hartke, 405 U.S. 15, 25 (1972).

77. See Tribe, 115 Harv. L. Rev. at 263-68 (cited in note 2).

78. In an carlier article, Professor Lund claimed that the Court did not forbid the Florida Supreme Court from conducting a statewide recount under uniform standards. Lund, Unbearable Rightness, supra note 4, at 1276 (cited in note 4). Au contraire:

December $12 \ldots$ is upon us, and there is no recount procedure in place ... that comports with minimal constitutional standards. Because it is evident that any recount seeking to meet the December 12 date will be unconstitutional ... we reverse the judgment of the Supreme Court of Florida ordering a recount to proceed. ... Justice Breyer's proposed remedy-remanding to the Florida Supreme Court for its ordering of a constitutionally proper contest until Decernber 18 -contemplates action in violation of the Florida election code, and hence could not be part of an "appropriate" order authorized by Fla. Stat. $\S 102.168(8)$ (2000).

Bush, 531 U.S. at 110-11.

79. See United States v. Mosley, 238 U.S. 383, 386 (1915) (noting that "the right to have one's vote counted is as open to protection" as the right to cast a ballot); see also South v. Peters, 339 U.S. 273, 279 (Douglas, J., dissenting) (arguing that the "right to vote includes the right to have the ballot counted"). It is simply not true, as Professor Lund suggests, that the Court had no reason to consider the underlying inequalities. See, e.g., Brief Amicus Curiae of the National Bar Association in Support of Respondents at 6-10, Bush v. Gore, 531 U.S. 98 (2000) (arguing that numerous legal votes remained uncounted and that the Fourteenth Amendment forbids disregarding legally cast votes in the name of finality).

80. Professor Lund claims that such a remedy would order "the Florida court to violate Florida law as construed by the Florida Supreme Court." Lund, Unbearable Rightness at 1275 (cited in note 4). So what? The Equal Protection Clause trumps state law, 
The closest Professor Lund comes to a response is his argument that the Supreme Court had no reason to consider the inequalities of the underlying count because no one ever "proved any such thing in court. Indeed, Gore never alleged any such thing." ${ }^{81}$ This argument defies common sense. First, precedent counseled in favor of resolving any existing inequalities via inclusion rather than ignoring them through exclusion. ${ }^{82}$ At a minimum, the Court should have justified its departure from this constitutional norm. Second, examples of such inequalities abound from even a cursory reading of the Gore v. Harris opinion. ${ }^{83}$ And even if one were capable of missing those examples, it is madness to think that the inequalities of the underlying count were somehow peripheral side-notes in Bush v. Gore. To the contrary, it was the existence of thousands of uncounted votes, many of which were tossed aside by disparate counting standards, that formed the very basis of the remedy the Court overturned! The right to have one's vote counted was the core of Vice President Gore's state suit from the very start. Finally, Professor Lund cannot simultaneously argue that the Florida Supreme Court acted improperly by "selectively" choosing the remedy suggested by the parties while praising the U.S. Supreme Court for acting with restraint by resisting the temptation to eliminate "all inequalities in a state's election process[]." 84

The remedy was and remains indefensible. There is thus no doubt that much of the outrage directed at the Bush v. Gore majority has its genesis in the perception that the Court simply handed the presidency to its favored candidate, or at least to the candidate whose rapid and assured victory it preferred to a period of prolonged uncertainty and a potentially untidy presidential transition. Given the likelihood that Bush would have won a statewide recount anyway, ${ }^{85}$ the Court could have minimized the

and forcing the Florida court to violate its own law is precisely what the Court did when it reversed the Florida Supreme Court's manual recount order-an order that Florida's highest court had determined was required by Florida statute - and "remanded for further proceedings not inconsistent with this opinion." Bush, 531 U.S. at 111.

81. Lund, EQUAL PROTECTION at 559 (cited in note 2)

82. See Karian, 79 N.C. L. Rev. at 1363 (cited in note 61).

83. 772 So. $2 d$ 1243, 1258-61 (Fla. 2000).

84. Lund, EQUAL PROTECTION at 559 (cited in note 2).

85. In part III of his essay, Professor Lund attacks me for arguing "that Bush would almost certainly have become President even if the Court had not decided this case in his favor, and that this would have been apparent to the Justices when they decided Bush v. Gore." Lund, EQUAL PROTECTION at 567 (cited in note 2). Lund drops one shoe by using my hindsight-driven reflection to engage in a bit of pop-psychoanalysis - I fabricated this prediction, he suggests, in order to demonstrate my ability to stay above the fray of gross partisanship-and then drops the other shoe by citing supposedly contradic- 
perception that it was engaging in pure politics had it simply allowed the political process to take shape. The Court insisted on just such an approach when it considered the closest Senate election in Indiana history. In Roudebush v. Hartke, ${ }^{86}$ the Supreme Court forbade a federal district court from shutting down a state manual recount process (on federal constitutional grounds) once a challenger had properly invoked state laws to contest the certification of his opponent. ${ }^{87}$ Recognizing that a contested election certification was but a midpoint in an ongoing electoral process, the Court chose to allow that process to run its course: "A recount is an integral part of the ... electoral process and is within the ambit of the broad powers delegated to the States." As we shall soon see, the existence of an ongoing political process should have dictated much more than the question of what remedy to impose.

tory testimony from my co-counsel, Ron Klain. Id. at 568.

With all due respect, Professor Lund's "argument" is silly. First, after-the-fact studies have now confirmed what many people suspected: even under the recount specifically ordered by the Florida Supreme Court, it is likely that Bush would have "won" by almost 500 votes. See Ford Fessenden and John M. Broder, Study of Disputed Florida Ballots Finds Justices Did Not Cast the Deciding Vote, N.Y. Times A1 (Nov. 12, 2001). But see Martin Merzer, The Miami Herald Report: Democracy Held Hostage 9-11 (2001) (arguing that Gore would have won a statewide recount under the Florida Supreme Court's "intent of the voter" standard but that Bush would have won under more detailed substandards).

Second, Professor Lund inexplicably equates my best guess about what the majority "could readily have calculated," with my own personal prediction, made in the midst of a whirlwind of litigation, of what was likely to happen. Of course I believed at that point that a Gore victory was still possible. Yet by December 8 , I had begun to have doubts whether Gore could win under any conceivable scenario. And even while I retained hope, it still seems plain to me in retrospect that the members of the Court who voted to grant certiorari and joined the per curiam opinion would have assumed as of December 9 that, given the structural resolution dictated by the Constitution and the political composition of both the Florida legislature and the U.S. Congress, a Bush victory was exceedingly likely even without the Court's action to prevent a resumption of the recount process. The main questions were how long that victory would take and how messy it would be.

Third, Lund's attack seems completely baseless when one realizes that he made almost exactly the same observation in an earlier article: "the passing of the December 12 'safe harbor' deadline would virtually have assured intervention by the Florida legislature... The legislature was already gearing up to appoint a slate of electors directly. Given the makeup of the Florida legislature, and the fact that Bush was the certified winner of the election, it is safe to assume that a slate of electors pledged to Bush would have been selected." Lund, Unbearable Rightness, at 1272 (cited in note 4). One might doubt the power of the Florida legislature to make such a move, but the Bush v. Gore majority clearly did not. See Bush, 531 U.S. at 104 (per curiam) (noting that Florida could "take back the power to appoint electors ... at any time"). If that slate had been selected, the matter would have proceeded (if at all) to the U.S. Congress, where no one predicted a victory for Vice President Gore.

86. 405 U.S. 15, 25 (1972).

87. Id. 


\section{DEFENDING THE "SPECTACULARLY INDEFENSIBLE"-THE POLITICAL PROCESS DOCTRINE}

Professor Lund devotes the second section of his comment to attacking my belief-indeed, labeling it "spectacularly indefensible" 88 - that Bush $v$. Gore presented a nonjusticiable political question. In essence, my argument was that the Twelfth Amendment, ${ }^{89}$ supported by the 1887 Electoral Count Act, textually committed to Congress the power to resolve electoral disputes in presidential elections, thereby precluding the heavyhanded judicial resolution imposed by the Court when it reversed the Florida Supreme Court's order to conduct a manual recount.$^{90}$ Indeed, I argued that the Court never should have stayed the recount, nor should it have granted certiorari in either of the cases it eventually heard. The Twelfth Amendment's delegation to Congress of the power to resolve disputes over the legitimacy of electoral votes constituted the grand finale of the Constitution's deliberately contemplated political process that, rather than being derailed and taken over by the Supreme Court at the first sign of potential defect, should instead have been al-

88. Lund, EQUAL PROTECTION at 562 (cited in note 2). It is interesting to note that Professor Lund's first reaction to the political question doctrine argument was significantly more measured. See Nelson Lund, An Act of Courage: Under Rehnquist's Leadership, the Court did the Right Thing, Wkly. Std. 19 (Dec. 25, 2000) (describing as a "plausible interpretation of the Constitution" the belief that the "Twelfth Amendment assigns Congress (rather than the federal courts) the responsibility for correcting such problems").

Professor Lund's more recent contention that the political question doctrine is plainly inapplicable dismisses out-of-hand numerous contributions made by many commentators of diverse political stripes. Although I have long believed that the Constitution grants Congress the primary responsibility for resolving presidential election disputes, see Laurence H. Tribe and Thomas M. Rollins, Deadlock: What Happens if Nobody Wins, Atlantic Monthly 49,61 (Oct. 1980), I was not the first, nor the last, person to raise such an objection to Bush v. Gore. See, e.g., Steven G. Calabresi, A Political Question, in Bruce Ackerman, ed., Bush v. Gore: A Question of Legitimacy 129-41 (Yale U. Press, 2002); Jeff Polet, The Imperiousness of Bush v. Gore, in David K. Ryden, ed., The U.S. Supreme Court and the Electoral Process 278-79 (2d ed. 2002); Jeffrey Rosen, Political Questions and the Hazards of Pragmatism, in Bruce Ackerman, ed., Bush v. Gore: $A$ Question of Legitimacy at 145-62; Erwin Chemerinsky, Bush v. Gore Was Not Justiciable, 76 Notre Dame L. Rev. 1093, 1105-09 (2001); Samuel Issacharoff, Political Judgments, 68 U. Chi. L. Rev. 637, 639-41(2001).

89. U.S. Const., Amend. XII ("The President of the Senate shall, in the presence of the Senate and House of Representatives, open all the certificates and the votes shall then be counted. ...").

90. For a fuller version of this argument, see Tribe, 115 Harv. L. Rev. at 276-87 (cited in note 2). See generally Laurence H. Tribe, 1 American Constitutional Law $\$ 3-13$ (Foundation Press, 3d ed. 2000). 
lowed to run its course in order to express the "respect due coordinate branches of government." ${ }^{\prime \prime 1}$

Professor Lund is right to criticize some of the language I used in my first formulation of this argument. Indeed, with the benefit of hindsight, it seems obvious to me that I approached this question too mechanically the first time around. Justiciability is "not a legal concept with a fixed content" of a rule-like character. Rather, it is a richly-textured doctrine whose proper application is inextricably linked both with the institutional context in which judicial intervention is sought (including the remedial character such intervention would have to take) and with the substantive principles of constitutional law that lie at the foundations of the allegedly "political" question at issue. In Bush $v$. Gore, a case that moved at dizzying speed and involved an unprecedented interplay of institutions in a confusing maze of legal challenges, it seems implausible that any resolution of the ultimate legal battle over the propriety of the Court's intervention in the face of the political question doctrine could be described as plainly right or as plainly wrong. It should not come as a shock, therefore, if "[t]he matter [would] not appear to me now as it appears to have appeared to me then." 93

There are obviously times when even the presence of an inherently "political question" does not foreclose the need for and propriety of judicial review. In McPherson $v$. Blacker, for instance, the Supreme Court held justiciable claims relating to the constitutionality of a district-based scheme for choosing presidential electors. ${ }^{94}$ The suit in Blacker was filed on May 2, 1891, one day after the legislature passed the challenged state statute and several months before the start of the presidential election that the law was designed to regulate. The Supreme Court of Michigan had already affirmed the constitutionality of the state law in question. There was no process by which petitioners could seek review other than through the Supreme Court. Nor was there a coordinate political branch or process that judicial action could be said to usurp. Congress was assigned no role by the Constitution in reviewing state legislative exercises of Article II responsibility. With no judicially irresolvable question, and no

91. Baker v. Carr, 369 U.S. 186, 217 (1962)

92. Poe v. Ullman, 367 U.S. 497, 508 (1961). Contra Marbury v. Madison, 5 U.S. (1 Cranch) 137, 170 (1803) (noting that "[q]uestions in their nature political . . can never be made in this court") (emphasis added).

93. Andrews v. Styrap, 26 L. T. R. (N. S.) 704, 406 (Baron Bramwell).

94. 146 U.S. $1,23-24$ (1892). 
parallel congressional process in place, review and remedy in the Supreme Court were entirely appropriate.

Moreover, it's quite easy in hindsight to think of different facts under which no "political question" argument could be persuasively marshaled against the Court's intervention in Bush v. Gore. Had the Florida Supreme Court put in place a statewide recount system that said "count the undervotes in precincts where the percentage of non-whites registered to vote was less than $10 \%$," waiting for the political process to correct the error would have been both unnecessary and wrong. Or, if the Florida court had said: "it is clear that the electoral process that our state legislature put in place prior to the election has resulted in a victory for an electoral slate committed to Governor Bush, but we think he'd make a bad president, so we will declare the Gore slate to have been duly selected on November 7," it would be obvious that the court's decision would have violated Article II of the Constitution. The reason that Bush v. Gore is not analogous is that the Florida court's decisions in those outlandish hypotheticals are so far outside of the range of constitutionally plausible actions that none of the traditional concerns presented by the political question doctrine would justify tolerating the undeniable offense to the Constitution created in each instance. ${ }^{95}$

It follows that the question posed by Bush $v$. Gore was not unambiguously "political" in the sense that no possible set of facts could have rendered the controversy justiciablesomething one can say of only a tiny subset of genuinely "political questions." Yet to admit seeing ambiguities is not to concede defeat. There are limited sets of constitutional matters that must be resolved by the political branches without judicial review. A Senator's vote against a bill, or a President's veto of a bill, on the ground that it violates the Constitution obviously cannot be reviewed by the Supreme Court. The "questions" resolved by such votes involve, among other things, textually demonstrable commitments to the political branches, a lack of manageable standards by which to resolve potential challenges, and the potential of embarrassment "from multifarious pronouncements by various departments on one question."

But those familiar Baker v. Carr standards do not tell us enough. Consider the case of Nixon v. United States, ${ }^{97}$ in which

95. Sec Baker, 369 U.S. at 217; sce also text at note 96.

96. See Baker, 369 U.S. at 217.

97. 506 U.S. 224 (1993). 
the Court pronounced that it had no authority to construe the meaning of the word "trial" in the context of a judicial impeachment. The majority in Nixon spoke as if the interpretation of what constitutes a "trial" would never be judicially reviewable. It seems plain to me, however, that what the Court must have meant was that the Senate had not gone outside the broad range of interpretations that could be considered acceptable, given the Constitution's textual commitment to the Senate of the sole power to try impeachments and given the functional considerations that the Court adduced in discussing the way in which a role for the Court in closely or routinely overseeing the impeachment of federal judges could undermine the legitimacy of the Court itself. ${ }^{98}$ Extracting this meaning from Nixon's holding isn't as difficult as reading tealeaves. Any first year law student could readily dream up hypothetical impeachment proceedings that the Court would probably feel compelled to review: an impeachment decided by a coin flip, a decision delegated solely to the two Senators who represent the state in which the accused judge resides, or an impeachment justified solely on the basis of a judge's religion would all plainly be justiciable despite the existence of a textual commitment. The majority's arguable mistake in Nixon was its decision to express the political question holding in absolute terms. ${ }^{99}$ But if it was a mistake, it was a typical one. Generally speaking, calling something a political question has served merely as shorthand for saying that the branch initially entrusted with making a decision-or, to put it another way, the institution to which the Constitution has granted the power to resolve such disputes-did so within the outer boundaries of its constitutional authority as policed by the Court. ${ }^{100}$

98. Nixon, 506 U.S. at 229-38 (1993). See id at 253-54 (Souter, J., concurring in the judgment) ("If the Senate were to act in a manner seriously threatening the integrity of its results, convicting, say, upon a coin toss, or upon a summary determination that an officer of the United States was simply 'a bad guy,' judicial interference might well be appropriate.") (internal citation omitted).

99. Justices White, Blackmun, and Souter argued for a more contextual, case-bycase review. See id. at 239-40 (White, J., concurring); id. at 252 (Souter, J., concurring).

100. See, e.g., Nixon, 506 U.S. at 229-38; Goldwater v. Carter, 444 U.S. 996 (1979) (plurality opinion) (finding nonjusticiable the question whether the President has the power to terminate treaties without approval of the Senate); but cf. id. at 1007 (Brennan, J., dissenting) (arguing that the political question doctrine, properly understood, "does not pertain when a court is faced with the antecedent question whether a particular branch has been constitutionally designated as the repository of political decisionmaking power" and explaining why "It]he issue of decisionmaking authority must be resolved as a matter of constitutional law, not political discretion" and thus "falls within the competence of the courts"). 
Perhaps, then, the real difficulty is that the political question doctrine really isn't about "political questions." Rather, the doctrine suffers from a "truth in advertising" problem - a problem to which I referred in my Harvard Law Review comment - that is hardly unique to the Court's decision in Bush v. Gore. ${ }^{101} \mathrm{Sim}$ ply put, the political question doctrine is misleadingly named; it really ought to be called the political process doctrine.

To illustrate how this political process doctrine has operated in practice even if not in name, it is important to consider not only cases like Nixon, where the Court found institutional comfort in describing as a "political question" ruling an adjudication that rested on an implicit determination that a coordinate branch of government had not in fact unacceptably exceeded its own constitutionally delegated powers, but also cases where the Court could not plausibly rely on this sort of implicit oversight of the political process to operate as a check on constitutional violations.

Recall that it was not until Baker v. Carr that the Court treated as reviewable the question whether the ground rules under which an election was about to take place satisfied equal protection norms. The pre-Baker Court wrongly treated all apportionment disputes as nonjusticiable, despite the absence of at least some of the traditional reasons for staying the judicial hand and the presence of truly egregious disenfranchisement or gerrymandering problems that the political branches simply refused to or could not realistically be expected to address. In many cases, these apportionment questions were considered "political" simply because they concerned politics. ${ }^{102}$ The Baker Court thus acted appropriately when it found such apportionment schemes subject to judicial review under the Fourteenth Amendment.

101. Professor Lund irresponsibly suggests that my "truth in advertising" critique of the political question doctrine was actually a critique of the Bush v. Gore Court. See Lund, EQUAL PROTECTION at 567 (cited in note 2) ("Or, adopting the language that Professor Tribe uses to attack the Supreme Court, one might say that his assertion does "not fare too well in the truth in advertising department.") (emphasis added) (internal quotation marks omitted). This entirely misunderstands my argument. See Tribe, 115 Harv. L. Rev. at 282 (cited in note 2).

102. See, e.g., Giles v. Harris, 189 U.S. 475, 487 (1903) (opinion by Holmes, J.) (holding that the Court could provide no remedy for Black plaintiffs who had demonstrated that they had been denied the right to vote explicitly on account of their race on the grounds that "equity cannot undertake now, any more than it has in the past, to enforce political rights"). The legal community owes a debt of gratitude to Professor Richard H. Pildes for bringing this nearly-forgotten abomination to widespread attention in Democracy, Anti-Democracy, and the Canon, 17 Const. Comm. 295 (2000). 
In later cases, the Court extended Baker's reasoning to cover the ground rules for a primary election, racial gerrymandering, and political gerrymandering. ${ }^{103}$ In these cases, two factors were usually present: first, the challenged state actor seems plainly to have violated some aspect of the Constitution; and second, there was no ongoing political process-recognized in the Constitution's institutional design - to review and resolve disputes of the sort presented so as to vindicate the constitutional values at stake. When the constitutional violation has been less clear, and especially when there has been a process in place fully capable of resolving the dispute in question and vindicating the right at stake, the political process doctrine has operated to deny, or at least postpone, judicial review.

Take, for example, the Court's unanimous decision in Growe v. Emison. ${ }^{104}$ In Growe, two challenges to the reapportionment of the Minnesota state legislative and federal congressional districts were proceeding simultaneously in state and in federal court. Redistricting plans emerged from both the federal and state suits, and the federal district court sought to enjoin enforcement of the state-initiated plan. The Court, through Justice Scalia, found that the abstention doctrine required the federal court to "stay its hands" until the state process had run its course. ${ }^{105}$ The Court's reasoning provides support for deference to the political process in cases like Bush v. Gore: "In the reapportionment context, the Court has required federal judges to defer consideration of disputes involving redistricting where the State, through its legislative or judicial branch, has begun to address that highly political task itself." ${ }^{106}$ Justice Scalia, along with all of his colleagues, concluded that, "[a]bsent evidence that these state branches will fail timely to perform [their] duty, a federal court must neither affirmatively obstruct state reappor-

103. See Anderson v. Celebrezze, 460 U.S. 780,789 (1983) (exercising judicial review over an Ohio statute regulating the presidential primary process); Gaffney v. Cummings, 412 U.S. 735, 751 (1973) (finding justiciable equal protection claims based on "purely political" gerrymandering allegations but holding that "bipartisan" gerrymandering did not run afoul of the Fourteenth Amendment); Fortson v. Dorsey, 379 U.S. 433, 439 (1965) (finding that redistricting that harms the voting strength of racial groups presented a justiciable question). Despite actively policing the use of race in districting plans, the Court has refused to invalidate districting plans designed to enhance the power of incumbents. Compare Shaw v. Reno, 509 U.S. 630, 651 (1993), with Davis v. Bandemer, 478 U.S. 109, 131-33, 143 (1986), and Gaffney, 412 U.S. at 752-54.

104. 507 U.S. 25 (1993).

105. Id. at 32 (citing Railroad Comm'n of Texas v. Pullman Co., 312 U.S. 496, 501 n.1 (1941))

106. Id. at 33. 
tionment nor permit federal litigation to be used to impede it."107 It is difficult to believe that the concurring opinion explaining the Bush v. Gore Court's grant of a stay on December 9, 2000, could have been written by the same hand: "Count first, and rule upon legality afterwards, is not a recipe for producing election results that have the public acceptance democratic stability requires." 108

Indeed, the reasoning in Growe applies perfectly to a dispute over which ballots to count in the midst of a presidential election. Once the election machinery has begun to grind awaya particular moment in time which depends entirely on the content of a state's election code-a process has been set in motion that does not conclude until the requirements of state and federal law have been exhausted. ${ }^{109}$ Once the political switch has been flipped to the "on" position, it is normally the political machinery to which micromanaging the process in accord with constitutional standards is and should be entrusted. Unless it is demonstrable that the process itself is structured in such a way that the political branches cannot be trusted to abide by constitutional norms, so that some impermissible form of exclusion or dilution in an identifiable individual's or group's rights of political participation might take place without adequate opportunity for timely correction within the process itself, the case for the deus ex machina of a judicial swat team leaping into the fray, halting the ongoing political process, and attempting to impose its own resolution, is pathetically weak in terms of our constitutional tradition. ${ }^{110}$

107. Id. at 34 .

108. Bush v. Gore, 531 U.S. 1046, 1046-47 (2000) (Scalia, J., concurring). It is even more surprising that Chief Justice Rehnquist was willing to agree to this type of ex ante invalidation when a single state court judge stood by to provide ex post review of individual ballot determinations. Cf. Ward v. Village of Monroeville, 409 U.S. 57, 62 (1972) (White, J., dissenting, joined by Rehnquist, J.) ("To justify striking down the Ohio system $[$-allowing mayors to sit as judges to resolve certain ordinance violations or traffic offenses-] on its face, the Court must assume either that every mayor-judge in every case will disregard his oath and administer justice contrary to constitutional commands or that this will happen often enough to warrant the prophylactic, per se rule urged by petitioner. I can make neither assumption.... I would leave the due process matter to be decided on a case-by-case basis ....").

109. See Weinberg, 82 Boston U. L. Rev. at 627-35 (cited in note 44).

110. This tradition dates back to Luther v. Borden, 48 U.S. (7 How.) 1 (1849) (hoiding that a federal court could not adjudicate a dispute over which of two competing governments was Rhode Island's real government and finding that Congress, under the guaranty clause, had the exclusive power to resolve the dispute); see also Pacific States Tel. \& Tel. Co.v. Oregon, 223 U.S. 118, 142 (1912) (holding nonjusticiable the question whether a state government is "republican" under the guaranty clause); cf. O'Brien $v$. Brown, 409 U.S. 1, 4 (1972) (noting that "[j]udicial intervention into [inherently political 
No doubt, there are times when the existence of a later process, capable of reviewing and correcting the alleged constitutional injury, does not by itself operate to render a judiciallyimposed remedy improper. When the constitutional right in question is a right to engage in a particular course of conduct free of any state chill or restraint, the state's deliberate interposition of an obstacle to that course of conduct may be void regardless of any process the state may have put in place to provide after-the-fact compensation. Thus, providing for ex post money damages, or pointing to the availability of redress through an open legislative process, would not prevent the judiciary from invalidating unconstitutional legislative restrictions on a woman's right to terminate a pregnancy. Even so, there are plainly other times when a state action temporarily imposes a burden or disadvantage on an individual or group in the course of an ongoing process of adjusting and adjudicating the costs and benefits of life in a complex society. In such cases, the constitutional harm is not considered complete or ripe for judicial review before that process has had an opportunity to engage in the selfcorrection anticipated by its design. Thus, the Takings Clause may not be deemed to have been violated when a constitutionally adequate avenue for just compensation remains open. ${ }^{111}$ It is in these contexts that the Rehnquist Court has routinely held that "postdeprivation remedies made available by the State can satisfy" the Fourteenth Amendment. ${ }^{112}$

The Bush v. Gore per curiam opinion's decision to halt the recount and freeze the result as certified by Katherine Harris is defensible only if whatever constitutional injury is said to have

processes] traditionally has been approached with great caution and restraint"); Taylor \& Marshall v. Beckham, 178 U.S. 548, 580 (1900) ("In the eye of the Constitution, the legislative, executive, and judicial departments of the State are peacefully operating by the orderly and settled methods prescribed by its fundamental law, notwithstanding there may be difficulties and disturbances arising from the pendency and determination of these contests."); see generally Tribe, 1 American Constitutional Law \& 3-13 (cited in note 90 ).

111. See Williamson County Reg. Planning Comm'n v. Hamilton Bank of Johnson City, 473 U.S. 172, 194 (1985) (holding that, when "the government has provided an adequate process for obtaining compensation, and if resort to that process [yields] just compensation, then the property owner has no claim against the Government for a taking") (internal quotation marks omitted).

112. Parratt v. Taylor, 451 U.S. 527, 538 (1981). Chief Justice Rehnquist authored the Parratt majority opinion. He there concluded that "either the necessity of quick action by the State or the impracticality of providing any meaningful predeprivation process, when coupled with the availability of some meaningful means by which to assess the propriety of the State's action at some time after the initial taking, can satisfy the requirements of procedural due process." Id. at 539. 
been done was complete and incapable of being averted or satisfactorily undone by whatever processes lay ahead. Plainly, no "injury" to candidate Bush could conceivably be so describedunless the very existence of some further political commotion on his way to the White House, or the possible discovery that someone else should be there in his stead, can be described as a constitutionally cognizable injury. Nor has anyone suggested any plausible "injury" to any identifiable set of voters in Florida that the recount, with all that lay ahead by way of corrective mechanisms, was bound to inflict and that a halt in the recount would prevent or remedy. Instead, the nature of the equal protection injury in Bush v. Gore most closely resembled that in the second category of cases described above. ${ }^{113}$ For the structure of the Florida Supreme Court's recount order of December 8, including the role it assigned to the state court judge in addressing alleged inequalities, left open numerous avenues for correcting procedural inequities in ballot counting. And the alleged inequities were so complicated and so attenuated that to argue that the Court had before it on December 8 a completed constitutional harm notwithstanding what the Florida courts and legislature, followed by Congress, might have done seems completely bizarre.

That is why nearly everyone - and I mean that literallywas stunned to see the Supreme Court leap in to adjudicate the deadline extension issue in Bush v. Palm Beach County. ${ }^{114} \mathrm{Nu}-$ merous political processes had already been put in place when the Court handed down its dispute-ending decree. First, although it was difficult (if not impossible) to discern any group of voters whose members were being denied the equal protection of Florida's laws, the Florida Supreme Court had set in motion a process designed to lead to a statewide recount to be supervised under a single, impartial magistrate. ${ }^{115}$ Second, the political branches of Florida's government, assisted by two extraordinarily capable Harvard Law Professors, stood by ready to act "on all the key questions." 116 And third, the Court had no reason to be-

113. See text at note 108 .

114. Bush v. Palm Beach County Canvassing Bd., 531 U.S. 1004, 1005 (2000) (granting certiorari and asking "[w]hat would be the consequences of this Court's finding that the decision of the Supreme Court of Florida does not comply with 3 U.S.C. Sec. 5?").

115. Professor Lund's claim that the Florida Supreme Court ordered a selective recount is, quite simply, a selective reading of the Gore v. Harris opinion. See Gore v. Harris, 772 So. 2d 1243, 1258-61 (Fla. 2000).

116. See Calabresi, $A$ Political Question at 141 (cited in note 88). Indeed, it was those very Professors (Charles Fried and Einer Elhauge) who filed a brief in the first 
lieve that the Congress would not act in a constitutional manner to resolve any dispute over what constituted the legitimate slate of Florida's electors had the issue come to the nation's capital.

Rather than let it come, the Court yanked the dispute from the Florida courts, canvassing boards, and legislature, only to decide it under the roof of a building never contemplated as a forum for presidential selection by Florida law or by the Constitution. At least three separate processes were underway. The very process halted by the Court in Bush v. Gore, the manual recount, was itself but a corrective step in an ongoing election designed to ensure that individual ballots were fully and fairly translated into votes. The last of the three processes - a combination of Article II, the Twelfth Amendment, and the Electoral Count Act - was designed to ensure the fair representation of each state in the electoral college. Yet the Court carved up complex, multi-step processes into baloney-thin slices - fixing its gaze upon the slice represented by the Florida Supreme Court's December 8 order-as though each were just one still shot in a sequence too complex to view in motion. ${ }^{117}$ And when the Court lifted just one single slice out of that rich national process in a way that disregarded the inequities the process was attempting to correct (however imperfectly) and the inequities its remedy left in place ${ }^{118}$ it upset the integrity of the very electoral college process which ensured that Bush defeated Gore despite the Vice President's capture of the popular vote. There is thus a strong connection between the veritable culture shock set off by the

round of litigation claiming that challenge before the Florida Supreme Court, and later before the U.S. Supreme Court, presented a nonjusticiable political question. See Brief of the Florida Senate and House of Representatives as Amici Curiae in Support of Neither Party at 7, Bush v. Palm Beach County Canvassing Bd., 531 U.S. 70 (2000).

117. See, e.g., Bush v. Gore, 531 U.S. 98, 109 (2000) (per curiam) ("Our consideration is limited to the present circumstances, for the problem of equal protection in election processes generally presents many complexities.").

118. At the time Bush v. Gore was decided, at least sixteen states besides Florida authorized manual recounts "without specifying a standard for counting ballots." Greene, Understanding the 2000 Election at 34-35 (cited in note 7). Additionally, as Justice Stevens's dissent pointed out, the majority of states employed either an "intent of the voter" standard or an "impossible to determine the elector's choice" standard in ballot recounts of various forms without specifying more specific substandards. See Bush, 531 U.S. at $124 \mathrm{n} .2$ (Stevens, J., dissenting). The absence of any successful constitutional challenge to these state laws helps explain why the rationale adopted by the per curiam opinion seemed all-too-convenient to so many observers. And the fact that no voters or political parties had challenged the constitutionality of such laws ex ante-unlike the Florida elections laws invoked by Vice President Gore, which had (in earlier forms) been used by previous candidates-should have signaled the Court that the ex post requests to invalidate the Florida Supreme Court's interpretation of those laws were self-serving political requests, not colorable claims for federal relief. 
Supreme Court's intervention in the presidential election of 2000 and the proper characterization of the Court's action as a violation of the implicit "political process" doctrine that has governed our national life without much interruption from the outset.

The shock brought about by the Court's intervention should have been less jarring in 2000 than it would have been a decade ago. As I have explained elsewhere, the Court's mistrust of the political branches-along with its "self-confidence in matters constitutional" - reached an all time high at the turn of the millennium. ${ }^{119}$ Meanwhile, the Court's tolerance for the rough and tumble of politics had reached an all time low. ${ }^{120}$ Most recently, in Republican Party of Minnesota $v$. White, ${ }^{121}$ the Court took the position, very much in tension with a strong belief in state sovereignty in structuring each state's processes of self-governance, that states had to make yet another all-or-nothing choice. According to White, states that have granted voters the right to participate in the selection of judges must choose either to abandon judicial elections altogether or to leave those elections free of any restraints in the course of a judicial campaign on what judges may announce about what view they take on issues likely to come before them if they are elected. ${ }^{122}$ In essence, states must purchase fairness and integrity and the appearance of both, and thus judicial legitimacy, at the price of excluding the public from direct participation in the process of selecting judges. Who were the five Justices in the majority? The same Justices that made up the Bush v. Gore five. ${ }^{123}$

Even if the Court had invoked the political question doctrine only to rule out remedies that prematurely short-circuited the political process, and had remanded the case to the Florida Supreme Court to conduct a manual recount with uniform stan-

119. Tribe, 115 Harv. L. Rev. at 288 (cited in note 2); cf. Rachel E. Barkow, More Supreme Than Court? The Fall of the Political Question Doctrine and the Rise of Judicial Supremacy, 102 Colum. L. Rev. 237, 242-43 (2002) (arguing that the Court should have applied the political question doctrine to the Article Il question in both Bush v. Palm Beach County Canvassing Board and Bush v. Gore; that the Justices' failure even to address the political question problem in the case is evidence that the doctrine no longer operates as an effective check on judicial supremacy; and suggesting that a casual assumption of judicial supremacy also manifests itself in the Court's lack of respect for congressional exercises of power under Article $I$ and Section 5 of the Fourteenth Amendment).

120. Id. See also Richard H. Pildes, Constitutionalizing Democratic Politics, in Ronald Dworkin, ed., A Badly Flawed Election: Debating Bush v. Gore, the Supreme Court, and American Democracy 176-86 (2002).

121. 122 S. Ct. 2528 (2002).

122. Id. at $2541-42$.

123. Id. at 2531 . 
dards, it would at least have remained somewhat faithful to our constitutional tradition. Thus, in Gilligan v. Morgan, ${ }^{124}$ the Court found nonjusticiable the question whether the training of the Ohio National Guard complied with the Fourteenth Amendment. The Gilligan Court did find that the training and control of military personnel pose quintessentially legislative and executive questions. Yet it cannot be doubted that, had the Gilligan petitioners proffered evidence that Ohio had trained its guardsmen explicitly to shoot at black students, and never to shoot at white students, the violation of the Fourteenth Amendment would have been so plain as to present a judiciable question despite the difficulties inherent in the judicial management of traditional military functions. Recall, though, that the plaintiffs in Gilligan asked the federal courts to create new standards to govern the training of the Ohio National Guard. ${ }^{125}$ It was thus not the subject matter of National Guard training itself that led the Court to invoke the political question doctrine; it was the particular type of judicial remedy-a heavy-handed form of judicial supervision over traditionally political functions - that the Court found precluded by the political question doctrine. The Court concluded that "[i]t would be difficult to think of a clearer example of the type of governmental action that was intended by the Constitution to be left to the political branches directly responsible - as the Judicial Branch is not - to the electoral process." ${ }^{126}$ Bush v. Gore answered the Court's challenge.

Was this "political process" doctrine relevant to the Bush v. Gore Court, or does this part of my comment represent only the fringe views of a disgruntled law professor? Professor Lund clearly believes the latter, arguing that neither I nor any Supreme Court Justice relied upon the political question doctrine when Bush v. Gore was litigated and ultimately decided. ${ }^{127}$ Lund is wrong, at least with respect to the Justices.

Contrary to Lund's utterly bizarre assertion, Justices Breyer and Souter plainly invoked the political question doctrine. Justice Souter argued that the Court "should not have reviewed"

124. 413 U.S. 1 (1973).

125. See id. at 6 (noting that the respondents "further demand, and the Court of Appeals' remand would require, that the District Court establish standards for the training, kind of weapons and scope and kind of orders to control the actions of the National Guard" and that, if respondents prevailed, the District Court would be forced to "assume and exercise a continuing judicial surveillance over the Guard to assure compliance with whatever training and operations procedures may be approved by that court").

126. Id. at 10 .

127. See Lund, EQUAL PROTECTION at 562-567 (cited in note 2). 
either of the two cases it eventually heard. ${ }^{128}$ "If this Court had allowed the State to follow the course indicated by the opinions of its own Supreme Court, it is entirely possible that there would ultimately have been no issue requiring our review, and political tension could have worked itself out in the Congress following the procedure provided in 3 U.S.C. $\S 15 .,{ }^{\prime 29}$ Armed with a more textured understanding of the political question doctrine, we can see how Justice Souter's argument invokes both the traditional doctrine and what I have called its political process variant. Second, like the Gilligan Court, Justice Souter invoked the political process doctrine with respect to the per curiam opinion's remedy: "[t]he case being before us, however, its resolution by the majority is another erroneous decision." ${ }^{130}$ Justice Souter would have remanded the case to the Florida Supreme Court to adopt uniform standards for counting disputed ballots, finding "no justification for denying the State the opportunity to try to count all disputed ballots now." 131

Like Justice Souter, Justice Breyer plainly believed that the appropriate remedy was to remand the case to the Florida Supreme Court to develop a "single-uniform substandard." like Justice Souter, Justice Breyer believed that "no preeminent legal concern, or practical concern related to legal questions, required this Court to hear this case, let alone to issue a stay that stopped Florida's recount process in its tracks." ${ }^{133}$ Justice Breyer mapped out a more elaborate argument than Justice Souter, though. He noted that the Constitution, federal statutes, and Florida law all combined to "set forth a road map of how to resolve disputes about electors" that "nowhere provides for involvement by the United States Supreme Court."134 Justice Breyer then used the precise language of Baker v. Carr, arguing that the Twelfth Amendment "commits to Congress the authority and responsibility to count electoral votes."

128. Bush, 531 U.S. at 129 (Souter, J., dissenting).

129. Id. (emphasis added). See also id at 130 (arguing that even a dispute over whether Florida intended to comply with the "safe harbor" statute "is to be made, if made anywhere, in the Congress").

130. Id. at 129.

131. Id. at 135 .

132. Bush, 531 U.S. at 146 (Breyer, J., dissenting).

133. Id. at 152 .

134. Id. at 153.

135. Id. (emphasis added). Justice Breyer also cited the Electoral Count Act of 1887 , 24 Stat. 373,3 U.S.C. $\$ \S 5,6$, and 15 , and its legislative history, to make the claim that congressional legislation, as well as the Constitution, evinced an existing political process to which the Court should have deferred. Id. at 154. 
Breyer's warning of a loss of public confidence in the Court, which Professor Lund has inexplicably decided is the only relevant part of the Breyer opinion, is ancillary to Breyer's central conclusion: "[T] here is no reason to believe that federal law either foresees or requires resolution of such a political issue by this Court. ... I think it not only legally wrong, but also most unfortunate, for the Court simply to have terminated the Florida recount. Those who caution judicial restraint in resolving political disputes have described the [characteristics of the] quintessential case ... [ $\mathrm{t}]$ hose characteristics mark this case."13

The responsibility for raising the political question argument should not have fallen solely upon Justices Breyer and Souter. The other seven Justices had a duty to discharge their constitutional responsibility as well. Justice Scalia, for instance, might have recalled the principles he elaborated in his Growe v. Emison opinion. Likewise, Justice O'Connor and Chief Justice Rehnquist ought to have been particularly sensitive to the argument. Justice O'Connor, joined by then-Justice Rehnquist, had penned a powerful concurring opinion in Davis v. Bandemer ${ }^{137}$ that should have counseled deference to the political process in Bush v. Gore. In that opinion, Justice O'Connor and Chief Justice Rehnquist agreed that an apportionment scheme that intentionally placed individual voters into different political districts in order to maximize one party's political strength was both nonjusticiable and, even if justiciable, insufficient to state a claim under the Fourteenth Amendment. The combination of the plurality opinion and Justice O'Connor's concurrence meant that at least one group of plaintiffs, black voters from center-city Indianapolis who "found themselves placed in multimember, predominantly Republican districts," suffered an unquestionable and arbitrary dilution of their voting power in order to preserve one party's hold on power. ${ }^{138}$ This fact did not sway Justice O'Connor or Chief Justice Rehnquist:

[T] he legislative business of apportionment is fundamentally a political affair, and challenges to the manner in which an apportionment has been carried out ... present a political question in the truest sense of the term. To turn these matters over to the federal judiciary is to inject the courts into the most heated partisan issues... [T] he Framers of the Constitution

136. Id. at 155,157 (emphasis added).

137. 478 U.S. 109, 144-61 (1986) (O'Connor, J., concurring).

138. See Samuel Issacharoff, Pamela S. Karlan, \& Richard H. Pildes, The Law of Democracy: Legal Structure of the Political Process 883 (Foundation Press, 2d ed. 2001) 
[did not intend] the judicial power to encompass the making of such fundamental choices about how this Nation is to be governed.... There is no proof before us that political gerrymandering is an evil that cannot be checked or cured by the people or by the parties themselves. ${ }^{139}$

If a pre-election scheme intentionally designed to entrench one political party at the expense of a discernable group of voters was nonjusticiable then, it is difficult to understand how a during-election court order designed to count ballots cast by voters of unidentifiable parties ${ }^{140}$ under the supervision of a singlemagistrate could be justiciable now. ${ }^{141}$

Professor Lund has at least one thing right: "Tribe the litigator" did not advance on behalf of Vice President Gore what now appears to me to be the correct formulation of the political process doctrine. I could try saying that I thought something like that formulation was inherent in my client's pleas for judicial restraint and deference to the legal and political processes set in motion under Florida's election code, and that I was content to leave explicit invocation of the political question doctrine to counsel for the Florida Legislature. ${ }^{142}$ Or I could try saying that I knew my client would veto the political process argument if I were to advance it. ${ }^{143}$ But I would be lying. The truth is that, in the whirlwind of that moment, I assumed that the Article II and Equal Protection Clause challenges to what the Florida Supreme Court had done on Vice President Gore's behalf on December 8 in ordering a statewide recount under the rules that the court put in place were justiciable, taking the simplistic, binary view of the matter that Professor Lund sets forth in his reply. In my Harvard Law Review comment, I leaned too far in the direction of nonjusticiability, in essence overcompensating for my earlier as-

139. Davis, 478 U.S. at 145-52.

140. Any arguments that assumed the party-identification of the voters in the Goreselected counties were just that: assumptions.

141. I have not conveniently latched onto Justice O'Connor's opinion to support my argument. I praised Justice O'Connor's Davis opinion for presenting "shrewd analysis" shortly after the decision. See Laurence H. Tribe, American Constitutional Law \$3-13, at 105 (2d ed. 1988). Still, I continue to have reservations about a complete retreat from judicial review of political gerrymandering. See note 42.

142. See Brief of the Florida Senate and House of Representatives as Amici Curiae in Support of Neither Party at 7, Bush v. Palm Beach County Canvassing Bd., 531 U.S. 70 (2000).

143. Vice President Gore made a similar decision when he refused to challenge irregularities in numerous military ballots from overseas. See Ronald A. Klain and Jeremy B. Bash, The Labor of Sisyphus: The Gore Recount Perspective, in Overtimel The Election 2000 Thriller 157 (Longman, Larry J. Sabato, ed. 2001). 
sumption of justiciability. With the benefit of hindsight, I have tried to articulate a more nuanced understanding of how to assess whether the Court should have intervened in Bush v. Gore, or, at a minimum, how to decide what remedy was proper, than either the one I acted on in December 2000 or the one I articulated in November 2001. "If there are other ways of gracefully and good-naturedly surrendering former views to a better considered position, I invoke them all." 144

\section{CONCLUSION}

My journey has led me back to where I first began: Bush $v$. Gore was wrongly decided. It is no more right today than it was on December 12, 2000, although my reasons for that conclusion have evolved since that time. I am grateful to Professor Lund for making the wrongness of the decision even clearer than it was before he undertook to defend it as clearly right. I believe I understand the constitutional problems that Bush v. Gore surfaced more deeply now than I did two years ago, one year ago, even one month ago. Yet familiarity brings little comfort. Rather, after studying the case for over two years, and after reflecting on a career spent studying, observing, and making arguments in the Supreme Court, Bush v. Gore-unlike a wrong decision whose eventual overruling one can seek to achieve and can anticipate with a degree of comfort ${ }^{145}$ - seems not just wrong, but unbearably so.

144. McGrath v. Kristensen, 340 U.S. 162, 178 (1950) (Jackson, J., concurring).

145. An example is Lawrence v. State, 41 S.W.3d 349 (Tex. App. 2002), cert. granted, Lawrence v. Texas, 123 S. Ct. 661 (2002), which I anticipate will overrule Bowers v. Hardwick, 478 U.S. 186 (1986), if it does not render an equally bold if ostensibly narrower equal protection holding. 